\title{
CRITERIAL DEVICE OF STUDYING THE FORMING STATE OF PARTNERSHIP RELATIONS BETWEEN TEENAGERS IN SECONDARY EDUCATION ENVIRONMENT
}

\author{
INNA CIMSIT
}

\begin{abstract}
The article summarizes scientific approaches and presents the classification of components, criteria indicators and levels of forming partnerships between teenagers. Within the framework of the given classification, three components of forming teenagers partnerships are studied, namely, motivational-value component, which corresponds to the axiological criterion, cognitive component, which is determined by operational-cognitive criterion, and activity component, which is characterized by behavioral-activity criterion. For each of the criteria there were identified corresponding indicators and levels. It is proved that axiological criterion in this area includes the following indicators: the indicators based on the development of forming teenager partnership through activating motivational and value interests and needs of an individual; the indicators defined in the context of focus on social responsibility of teenagers, which are conditioned by partnership. It is established that among the indicators related to the operational-cognitive criterion in this area include: the indicators based on selecting their elements particularly for the specified age group (age determining approach); the indicators based on elements of awareness and perception; the indicators defined in the context of reference to the constructive results of forming knowledge and skills from the partnership relations between teenagers (constructivist approach). The indicators of the mentioned category are formed by the emphasis on the attributive approach to educational activities. It is determined that the indicators of the behavioral criterion include: focus on joint participation in partnerships through the possibility of implementing certain joint partnership activities (actions); emphasized on efficiency, effectiveness and synergy. The structure and the content of this classification considers the main scientific approaches in the denoted area, providing for the universalization of modern scientific thought, since it takes into account most of the views and features of these structural components of the teenagers partnership. The points of the given classification can be used for creating methodological support for evaluating this issue. Therefore, the indicators and levels identified in the study can act as assessments. It is established that the defined features of the specified components criteria and indicators as well as their levels correspond to the features of the studied age group of teenagers of school educational environment.
\end{abstract}

Keywords: motivational evaluative component, cognitive component, activity component, partnership relations between teenagers, constructivist approach, social responsibility, attributive approach, efficiency. 


\section{INTRODUCTION}

One of the critical stages of research in pedagogical and psychological areas and processes is to define the criterion device of study. Based on the substantivated structure of teenagers partnership. In the course of our research we have worked out criteria indicators and levels of forming teen-agers partnership relations in the educational environment of secondary education (SE). Under the criteria we understand an evaluative means of judging the state of development of a personality components, and thus, their content is formed on the requirements of objectivity, adequacy, additivity and quantity. In this case, the indicators act as the elements of each of the criteria determining the state of typical features and the essence of the studied phenomenon (V. Zhelanov [18]). The presented evaluative indicators of the studied criteria provide for manifesting features and peculiarities within each component of personality development. However, in our research the emphasis was laid on age peculiarities. On determining the levels of forming indicated criteria we carried out and considered possible manifestations of certain indicators within the age parameters of teenagers of the 5-6 grades in the educational environment of secondary education. Given the fact that the question of teenagers partnerships has not been widely covered in the scientific and methodological literature, thus, the study of the subject is topical.

\section{THEORETICAL BACKGROUND}

The presented research is carried out according to the ideas and views of various scientific works devoted to the definition of methodical aspects for assessment of the conditions in which partner relations between teenagers are formed, the criterion device of analyzing the processes, the phenomena and features of participants in the educational environment. These are, in particular, the works of: A. Burelomova, V. Zhelanova, A. Priymak, O. Dorontsova, M. Zaitseva, D. Ushakov, A. Crawford, E. Saul, S. Matthews, J. Mackinster, N. Drozdova, D. Voitkevich, T. Gordeeva, G. Shigabetdynova, O. Lavrentieva, O. Kokhanova, Y. Kapusta and V. Onipko, S. Ivanov, K. Struzhynsky, etc.

\section{Research Objective, Methodology and Data}

The objective of the article is to systematize scientific approaches to the methodological support of components, criteria, indicators and levels of forming partnerships between teenagers in the educational environment of SE. The object of the research is the components, criteria, indicators and levels of forming partnerships between teenagers in the educational environment of SE. The methodological basis of this study are the following: the method of generalization and the method of a systematic approach.

\section{RESULTS AND DisCUSSION}

Having analysed theoretical aspects of developing partnerships between teenagers, we found that this phenomenon is formed on the basis of the essential feature of the motivational and value component (reference to common life, social, educational interests and norms (depending on age and social characteristics of participants)), cognitive component and forming knowledge) (the impact of common targets for educational interests realization), the activity component due to the emphasis on the implementation of joint activities between partners (events, actions and processes). For a comprehensive and reliable assessment of formed partnerships between teenagers in Grades 5 and 6 in the educational environment of secondary education, it is necessary to create appropriate methodological support. Our defined methodology should consider the guideline for evaluative criteria and indicators of components (motivational-value, cognitive and activity), as well as to predict peculiar indicators of their development and identifying levels (according to the degree of achievement and effectiveness, etc.). As part of the methodological support, it is necessary to clearly categorise teenagers 
into the study groups according to the degree of forming their partnerships. Further on, the findings of the research can be used to create project methods of forming partnerships for relevant groups of teenagers with a particular level of studied phenomenon and its development.

Further, here our attempt to identify the main scientific approaches to systematize the indicators of the three components of forming partnerships between teenagers will be presented.

Axiological criterion that corresponds to the motivational evaluative component of partner relations. Indicated criterion reflects the state and nature of teenagers' attitude to values, their hierarchy, the degree of awareness and motivation to develop partnerships in the school environment. Now the main indicators of developing these criteria and the levels of their formation in the studied age group will be determined. The indicators of the axiological criterion in this area include the following:

1. The indicators of the mentioned category, based on the development of forming the partnerships between teenagers through activating motivational and value interests and needs of an individual. (According to the approach of G. Shigabetdinova [9]: the indicator of the need for partnerships can be expanded by spectra and areas of teenagers' and their interest in this phenomenon and participating in such a relationship. The indicator of clear motives existence for the development of partnerships can be categorized by the types of motives,namely: both common or collective and individual, as well as agreed and proposed, although, not agreed, but accepted by participants who do not actively affect partnerships, which, in turn, changes the course of the relationship of subordination to leaders), etc. The guideline for maintaining the common values within partnerships can be assessed in terms of different types of common values i.e. educational, environmental, the attitude on how to socialize, cultural such as participating in different or common social groups, real-life communities, on the Internet, etc. According to the author's approach [9], the constituent of indicators of mentioned category includes four elements, in particular: interest in mutual partnerships where the given feature of an individual is manifested at the developing stage; the need for partnerships - here the necessity for participating in such a kind of interaction is determined; and the concentration on maintaining the presence of common values of the partnership - common interests in life, social, educational, and other norms (depending on the age and social features of the participants); the existence of clear motives for the development of partnerships - defining the development and motivational aspects of the process. These indicators are generally highlighted in the study of the scholar, but their features and levels of manifestation are not formed. Resting upon those studies devoted to development of age peculiarities, we compiled the list and the essence of the denoted indicators, as well as determined the levels of their forming and manifestation by teenagers. Those are, the indicator of "Interest in partnerships" (manifested at the stage of their development) may have the following levels of manifestation: high level, indicating to an active orientation of the participant or teenager to the partnership. Its high value may be observed in informal leaders. Medium level, which points out to the average or vague orientation of the participant or a teenager to the partnership. Its medium value may be observed in teenagers who occupy a dependent or neutral position in the group. And low level, which demonstrates the passive orientation of the participant or a teenager to the partnership. Its low value can be observed in teenagers who take a dependent position in the group. The indicator of "Need for a partnership" (determining the necessity in participating in this interaction) denotes how teenagers understand this need, how they identify it, and how they are interested in this kind of interaction and mutual partnership. On evaluating this indicator, assessing methods of the different spectra and areas of teenagers' interest in this phenomenon can be chosen as well as participation in such a relationship. This indicator can be also distinguished by the following levels: high, where there is a high need of a participant teenager in a partnership, its high value can be observed in informal and formal leaders; medium, showing the medium need of the participant teenager in a partnership, its medium value can be observed in those teenagers who take a dependent or neutral position in the group; and low level, identifying the low need of the participant teenager in a partnership, its low value can be observed in teenagers who occupy a dependent position in the group. The indicator "Concentrating on maintaining the common values of partnerships" can be characterized by: optimal (or high) level, within which 
participants take an active position in partnerships. They are often their leaders (formal or informal) and they predominantly maintain in others (either dependent or not quite active participants) the concentration or the reference point for common values of partnership, they also determine the course of common classes, trainings, leisure programs with the appropriate team of teenagers and partners. Sufficient medium level, where is demonstrated the dependence of participants in this area; and the minimum (low) level, determining the passive attitude in a relation to these initiatives. The indicator of "existence of clear motives for developing partnerships" is defined at high, medium and low levels as well. In the manifestation of high level of partnerships leaders may have clear motives for their development, in particular, related to activating the latter to achieve common goals or a number of their own motives (which should not formally contradict the goals of others). Indicated motives may relate to both, the development of cognitive abilities, and personal goals or guidelines. At the age of Grades 5-6, many teenagers do not have a clear position in the partnership, but those who formed them demonstrate high features of the developing value-motivational component. Medium and low levels of manifesting this indicator characterizes, respectively, medium and low level of motivation for the development of the same process.

2. Indicators of the denoted type are defined in the context of focusing on social responsibility of teenagers in a partnership (in accordance with the approach by O Lavrentieva [10]). Further we will determine the composition of these indicators presented in the study of the author at the same time appropriately we will define their level of manifestation. Namely, among those we can distinguish the following: the indicator of "Awareness of social responsibility as values in relation to others"(including participants in partnerships at school); the indicator of "Acknowledgement of social responsibility as a personal value".);». It should be noted that the researcher proposes to assess the degree of manifestation of indicators in this category through four types of levels, in particular: passive, situational, stable and senseoriented [10]. Accordingly, indicated levels are located at the point of increasing manifestation that focuses on the social responsibility of teenagers in a partnership, considering the value of the relationships in the partnership. By analysing the definition of the features of each separate level of manifestation of these indicators we came to the point that shows that their highest level - sense-oriented level - may be inherent in leading partners who have a significant impact on these relationships. The following features of the levels of manifestation of these indicators were revealed. First of all, the indicator of "Awareness of social responsibility as a value in relation to others"(including participants in partnerships at school) can be determined by: the passive (low) level of awareness inherent to teenagers -partners who do not show initiatives and are dependent and passive; situational level, where predominantly are expressed external motives in the awareness of social responsibility as a value (for teenagers who situationally show initiatives in the partnerships); steady level, which is accompanied by demonstrating the value of social responsibility in familiar and unfamiliar situations (for teenagers who steadily show initiatives in the partnerships); sense-oriented level which is associated with the promotion and advocacy of the value of social responsibility among the participants of partnerships at school (for teenagers who deliberately show initiatives in their partnerships, those teenagers usually are leaders in groups). The indicator of "acknowlegement of social responsibility as a personal value" is associated with manifestations within such levels as: passive level, which is characterized by avoiding the acknowledgement of social responsibility as a personal value (for teenagers and partners who do not show initiatives, they are dependent and passive); situational level, which is determined by the awareness of the necessity of social responsibility as a value, but it is, at the same time, not included in the hierarchy of their own values (for teenagers who situationally show initiatives in partnerships); a steady level where the social responsibility is acknowledged as a personal value (for teenagers who steadily show initiatives in partnerships); sense-oriented level is determined by the awareness of including social responsibility in the rank of leading values (for teenagers who deliberately show initiatives in their partnerships and are leaders in their groups). In our opinion, the allocation of the above-mentioned indicators in the studied category of elements for social responsibility is an important identifier of the development of partnerships at the level of the school educational environment of 
teenagers. Therefore, there is a necessity to include indicators of this category in the motivational and value component of forming teenagers partnerships, which will be further determined in the author's proposal.

Cognitive component of the partnership corresponds to the operational-cognitive criterion. The indicators of development of partnerships between teenagers within this criterion are determined by the ability of the latter to focus on other teenagers with whom they interact. It may be related to acquiring, mastering, transferring and producing knowledge and skills, etc. Among the indicators of this category we may list the following:

1. Indicators based on singling out certain elements particular for a specified age group (age-based approach) (according to the approach by A. Burelomova [1]). Among the indicators of this category are the following: academic performance successes; curiosity; savvy; mind; rationality; erudition; wisdom; creativity; eloquence; ingenuity; logic; prudence; talent; and professionalism. According to the results of the given systematization, it can be noted that the author, guided by empirical research, proves that such indicators of the cognitive component as academic performance success or erudition have the highest level of development in grades 5-6, while other above-mentioned indicators at this age are medium or even low. This is explained by the fact that at this age teenagers are still continuing their development. It can be pointed out that such a natural cognitive ability as talent can be measured in certain areas (musical, mathematical or literary), but in the age group of 5-6 grades, as D. Ushakov justfully points out [2], it can be at a latent level. Therefore, we consider it to be more acceptable to separately allocate the IQ of this age group. Also, in our opinion, separating professionalism as part of cognitive component in forming partnerships between teenagers is quite controversial, since at this age the notion of professionalization is absent, and generally, for older age groups, especially young people, this indicator can be attributed to the activity component.

2. The indicators based on the elements of awareness and perception (according to the approach by M. Zaitseva [3]). The number of indicators in this category is determined by the range of elements through awareness of creative educational and normative (set of certain rules), as well as a moral nature, perception of self-development or self-education, etc. It should be noted that in the approach by M. Zaitseva [3] singled out the following: 1) the indicators of awareness of the normative nature: awareness of norms and rules of how to behave in the classroom; selecting how to make a dialogue as a form of interaction with peers; awareness of trust and friendliness and participant's intentions within the partnership relations; awareness of having the value to cooperate in the relations; 2 ) the indicators of awareness of a moral nature: awareness of moral norms of people coexisting in the society; perception of the partners' personality as a value; ability to listen, analyze and compare their point of view with the one of the partners'; the ability to choose for themselves which is a part of a divided collective task; the ability to find acceptable ways to resolve controversies or discrepancies occurring in the course of partnership, to identify optimal ways of ensuring the possibility for everyone to contribute in solving the common general task; ability to define and differentiate the functions of cooperation between the parties; awareness of the united goals in the process of cooperation; 3) the indicators of awareness of the creative nature: awareness of the necessity to find ways of creative selfdevelopment and self-learning; awareness of mutual responsibility and dependence; the ability to identify the necessary and the most effective ways to solve problems facing difficult life situations; prevailing certain attitudes to achieve a collectively significant goal; and the ability to perceive the process of solving a collective goal as an opportunity for self-development; the ability to acquire knowledge independently and collectively; the ability to form own conviction in efficiency and expediency of acquiring abilities and skills to cooperate; 4) the indicators of self-development and selfeducation perception: by taking own personality as a value; the ability to identify the most significant personality traits and qualities in organizing constructive interaction; the ability to compare and analyze the results of the activity with the results of other students; the ability to plan the process of self-development and self-education, including acquiring knowledge, abilities and skills of constructive interaction; the ability to make decisions independently and to take responsibility. In our opinion, the last three elements of the second indicator belong more to the indicators of awareness of the need to 
produce constructive knowledge, which can be allocated to a separate category. However, it should be noted that the indication of operating with knowledge in the framework of cognitive indicators is identified more as part of the fourth category of indicators (cognitive indicators of self-development and self-education perception). These indicators include an emphasis on the element of the ability to plan the process of self-development and self-education, those are as well directed to acquiring knowledge, skills and abilities of constructive interaction. It should be noted that the indicated element can be expanded due to the above-listed indicators of awareness of the necessity to produce constructive knowledge in terms of partnership and interaction. Despite the fact that the author's classification of indicators belonging to this category has certain debatable features, for attributing some evaluation elements to certain categories, we can state that this approach is multi-sided, as it takes into account a number of indicators and their evaluating components. As a whole, the approach by $\mathrm{M}$. Zaitseva generally assumes that the cognitive component of forming cooperation involves the conscious replacement of unproductive activity (impulsiveness or inflexibility of behavior) with productive activity (deliberateness and constructiveness) through the child's ability to reflect and comprehend the results of the interaction.

3. The indicators defined in the plane of the focus on constructive results of forming knowledge and skills from the partnership between teenagers (constructivist approach by O. Dorontsova [4]). These indicators include the following: analysis of contradictions in joint collective curricula; ability to predict learning process;, ability to plan learning; ability to set targets; ability to determine the criterial assessment of knowledge and skills (in relation to both, themselves and other participants of the partnership); ability to make decisions associated with mastering new knowledge; ability to make decisions regarding the production of new knowledge; ability to make decisions regarding the transfer of knowledge; ability to control themselves and others in the learning process; ability to adjust the learning process (in relation to themselves and other participants of the partnership); ability to selfmanagement and management of educational process (regarding themselves and other participants of partnership); creative potential (including certain spheres, subjects, narrow areas in the learning process). It may be noted that the set of indicators included to this category and presented in the study by $\mathrm{O}$. Dorontsova is quite comprehensive and multi-facet in the framework of the approach that is focused on constructive results of forming knowledge and skills from such relationships (constructivist approach). It is worth mentioning that by pointing out to such constructivist indicators as either the ability to make decisions of mastering new knowledge or the ability to make decisions about the production of new knowledge, or the ability to make decisions about the transfer of knowledge are found in the research works by A. Crawford, E. Saul, S. Matthews, J. Mackinster [5] and N. Drozdov [6]. By summarizing the approaches of the above-listed authors we may state that as part of the operational-cognitive criterion indicators, they propose to use the following: 1) a focus on participation in partnerships through the necessity of increasing the level of knowledge; 2) a focus on participation in partnerships through the necessity of transferring and producing new knowledge; 3) a focus on participation in partnerships through the acknowledgement of their value for acquiring knowledge and skills. Accordingly, here we may as well point outthat the authors make an emphasize on the constructivist approach to form partnerships between teenagers.. The constructivist signs of forming this phenomenon are more peculiar to teenagers who are leaders of partnership groups, although for other categories of teenagers of this interaction they are less significant.

Another approach which should also be mentioned here is constructive. It relates to the classification of operational-cognitive criteria indicators. Considering this approach another list of such indicators is compiled in the scientific work by D. Voitkevich [7]. It is determined that among the mentioned evaluative indicators are the following: a focus on knowledge transfer; a focus on consistent knowledge acquisition associated with theme and subject aspects; a focus on helping to solve cognitive problems and of acquiring knowledge and skills; a focus on skills development and knowledge transfer and production from other participants in partnerships; a focus on promoting the development in partners' ability to create target guidelines in the context of the learning process, an order of acquiring and producing knowledge and skills. In D. Voitkevich's research it is rightfully noted that a high level 
of identified constructivist indicators of this criterion can be applied if teenagers act as participants in a partnership and have a high level of cognitive intelligence. We should pay attention to the fact that a great significance of this combined indicator of teenagers-leaders cognitive ability is an absolute advantage for the partnership and its other participants.

4. The indicators of the denoted category formed within the emphasis on the attributive approach to educational activities. Within this approach, the structure of indicators of this category should be definitely noted. The later are given in the study by T. Gordeeva [8]. In particular, the author proposes to consider the following evaluative indicators: the indicators of self-control or control over other participants in the partnership (students of the same class with whom they study and master certain skills for participation in testings, trainings or competitions). The indicators of possessing knowledge and skills associating themselves and other participants. The indicators of the ability to determine the educational efficiency of other participants in partnerships and to evaluate self-efficiency in learning, studying, trainings, competitions, school championships, etc. These categories of indicators are of an attributive and demonstrative nature. They allow us to present information about certain achievements of the participants in the partnership in adolescent age. Although the emphasis in the ideas of the works by T. Gordeeva is laid on the attributive approach to educational activities within the indicators of operational-cognitive criterion, the author considered a fairly comprehensive list of evaluative elements in this area.

The activity component of forming partnerships between teenagers corresponds to the behavioralactivity criterion, which reflects the ability to implement knowledge and skills in practice. This relates to the effectiveness of participation in the process. The indicators of this criterion are:

1. Focus on joint participation in partnership relations through the possibility to implement certain common partnership activities or events (actions). (The approach by O. Kokhanova [11], Y. Kapusta, V. Onipko [12] and S. Ivanova [13]). The high level of manifesting this indicator is particular for teenagers taking an active position in the partnership and being able to act as leaders.

2. Focus on effectiveness efficiency and synergy (K. Struzhynsky's approach [14]). The author proves that at the level of adolescent age group of students we can single out three types of indicators that belong to the operational activity component. Those are:

1) indicators of defending activity - when a teenager being in a school environment establishes relationships with peers to simplify the process of obtaining certain results in the course of implementation of some educational tasks, trainings and curricula. At the same time, partnerships are at their forming stage. And as they have a forced nature for the teenager, they allow to protect the teenagers from getting bad grades in the learning process as well as from contempt of ignoring the collective activities.

2) indicators of compromise activity - when a teenager in a school environment enters into relationships with peers to obtain effective results in implementing certain educational tasks, trainings and curricula. Partnerships are at a developing stage, since they acquire some compromise features and are more conscious. The participants of the partnership relations have constantly growing mutual interest due to certain practical results obtained by the previous positive experiences.

3 ) indicators of synergetic effect - when a teenager in a school environment enters into relationships with peers to obtain additional results that may relate to both the learning process and social status. If such a teenager is the organizer of the relationships, he acquires the status of a leader, which increases his self-esteem. He can also have certain personal benefits from helping others. In particular, trust, positive attitude and respect from others.

Similar proposals of determining the indicators of this category in the context of the focus on effectiveness efficiency and synergy were brought out in the studies by I. Moravska [15], M. Shufnarovska [16] and E. Vesolovska [17]. It can be pointed that the indicating this evaluative focus is reasonably sound. To emphasize on all the above-said, we can state that the listed set of criteria and corresponding indicators is an important identifier of forming this phenomenon in the school environment. 
Guided by the above-listed approaches, we will have an attempt to formulate our own approach of classifying the criteria indicators and levels of forming partnerships between teenagers which is given below in the table 1. (Table 1)

\begin{tabular}{|c|c|c|c|c|}
\hline Criteria & Indicators & \multicolumn{3}{|c|}{ Forming Levels } \\
\hline \multirow[t]{5}{*}{$\begin{array}{l}1 . \\
\text { Axiological }\end{array}$} & $\begin{array}{l}\text { 1.1. Interest in partnership } \\
\text { relations is manifested at } \\
\text { their developing stage. }\end{array}$ & $\begin{array}{l}\text { High, the most } \\
\text { optimal level of } \\
\text { interest to the } \\
\text { partnership } \\
\text { relations }\end{array}$ & $\begin{array}{l}\text { Acceptable or } \\
\text { medium level of } \\
\text { interest to the } \\
\text { partnership } \\
\text { relations and to the } \\
\text { participation in this } \\
\text { interaction }\end{array}$ & $\begin{array}{l}\text { Low level of } \\
\text { interest to the } \\
\text { partnership } \\
\text { relations and to } \\
\text { the participation } \\
\text { in this interaction }\end{array}$ \\
\hline & $\begin{array}{l}\text { 1.2. Need in partnership } \\
\text { relations is determined by } \\
\text { the necessity in } \\
\text { participating in the } \\
\text { interaction. }\end{array}$ & $\begin{array}{l}\text { High and urgent } \\
\text { participation in the } \\
\text { interaction }\end{array}$ & $\begin{array}{l}\text { Medium level of } \\
\text { the necessity in } \\
\text { partnership } \\
\text { relations }\end{array}$ & $\begin{array}{l}\text { Low level of the } \\
\text { necessity in } \\
\text { partnership } \\
\text { relations }\end{array}$ \\
\hline & $\begin{array}{l}\text { 1.3. Focus on maintaining } \\
\text { common values of the } \\
\text { partnership relations such } \\
\text { as common life as well as } \\
\text { educational or social } \\
\text { interests and norms } \\
\text { which depend on age and } \\
\text { social features). }\end{array}$ & $\begin{array}{l}\text { Leading position in } \\
\text { maintaining } \\
\text { common values of } \\
\text { the partnership } \\
\text { relations }\end{array}$ & $\begin{array}{l}\text { Dependant } \\
\text { position in } \\
\text { maintaining the } \\
\text { common values of } \\
\text { partnership } \\
\text { relations }\end{array}$ & $\begin{array}{l}\text { Passive position } \\
\text { in maintaining the } \\
\text { common values of } \\
\text { partnership } \\
\text { relations }\end{array}$ \\
\hline & $\begin{array}{l}\text { 1.4. Existence of clear } \\
\text { motives of developing the } \\
\text { partnership relations lies } \\
\text { in identification of the } \\
\text { motivational aspects of } \\
\text { developing the mentioned } \\
\text { process }\end{array}$ & $\begin{array}{l}\text { Clear motivation of } \\
\text { developing the } \\
\text { partnership } \\
\text { relations }\end{array}$ & $\begin{array}{l}\text { Average } \\
\text { motivation } \\
\text { developing } \\
\text { partnership } \\
\text { relations }\end{array}$ & $\begin{array}{l}\text { Lack or low level } \\
\text { of motivation of } \\
\text { developing the } \\
\text { partnership } \\
\text { relations }\end{array}$ \\
\hline & $\begin{array}{l}\text { 1.5. Focus on } \\
\text { acknowledgement and } \\
\text { awareness of social } \\
\text { responsibility as a value } \\
\text { regarding others, } \\
\text { including the participants } \\
\text { of the partnership } \\
\text { relations at school }\end{array}$ & High level of focus & $\begin{array}{l}\text { Medium level of } \\
\text { focus }\end{array}$ & $\begin{array}{l}\text { Avoiding of the } \\
\text { acknowledgement } \\
\text { and awareness of } \\
\text { social } \\
\text { responsibility as a } \\
\text { value regarding } \\
\text { others, including } \\
\text { the participants of } \\
\text { the partnership } \\
\text { relations at school }\end{array}$ \\
\hline
\end{tabular}




\begin{tabular}{|c|c|c|c|c|}
\hline Criteria & Indicators & \multicolumn{3}{|c|}{ Forming Levels } \\
\hline $\begin{array}{l}2 . \\
\text { Operational } \\
\text {-cognitive }\end{array}$ & $\begin{array}{l}\text { 2.1. Focus on participating } \\
\text { in the partnership } \\
\text { relations through the } \\
\text { necessity of increasing the } \\
\text { level of knowledge. }\end{array}$ & $\begin{array}{l}\text { Active position of } \\
\text { participation in the } \\
\text { partnership } \\
\text { relations through } \\
\text { the necessity of } \\
\text { increasing the level } \\
\text { of knowledge and } \\
\text { the necessity of } \\
\text { transferring this } \\
\text { knowledge }\end{array}$ & $\begin{array}{l}\text { Insufficient or not } \\
\text { active position of } \\
\text { participation in the } \\
\text { partnership } \\
\text { relations through } \\
\text { the necessity of } \\
\text { increasing the level } \\
\text { of knowledge and } \\
\text { through the } \\
\text { necessity of } \\
\text { transferring this } \\
\text { knowledge }\end{array}$ & $\begin{array}{l}\text { Weak and passive } \\
\text { position of } \\
\text { participation in } \\
\text { the partnership } \\
\text { relations through } \\
\text { the necessity of } \\
\text { increasing the } \\
\text { level of } \\
\text { knowledge and } \\
\text { through the } \\
\text { necessity of } \\
\text { transferring this } \\
\text { knowledge }\end{array}$ \\
\hline & $\begin{array}{l}\text { 2.2. Focus on participation } \\
\text { in the partnership } \\
\text { relations through the } \\
\text { necessity of transferring } \\
\text { and producing new } \\
\text { knowledge }\end{array}$ & $\begin{array}{l}\text { Active position of } \\
\text { participation in the } \\
\text { partnership } \\
\text { relations through } \\
\text { the necessity of } \\
\text { transferring and } \\
\text { producing } \\
\text { knowledge }\end{array}$ & $\begin{array}{l}\text { Insufficient or not } \\
\text { active position of } \\
\text { participation in the } \\
\text { partnership } \\
\text { relations through } \\
\text { the necessity of } \\
\text { transferring and } \\
\text { producing } \\
\text { knowledge }\end{array}$ & $\begin{array}{l}\text { Weak and passive } \\
\text { position of } \\
\text { participation in } \\
\text { the partnership } \\
\text { relations through } \\
\text { transferring and } \\
\text { producing } \\
\text { knowledge }\end{array}$ \\
\hline & $\begin{array}{l}\text { 2.3. Focus on participation } \\
\text { in the partnership } \\
\text { relations through the } \\
\text { acknowledgement of their } \\
\text { value for obtaining } \\
\text { knowledge and skills }\end{array}$ & $\begin{array}{l}\text { Active position of } \\
\text { participation in the } \\
\text { partnership } \\
\text { relations through } \\
\text { acknowledgement } \\
\text { of the value of } \\
\text { partnership } \\
\text { relations } \\
\text { obtaining for } \\
\text { knowledge and } \\
\text { skills }\end{array}$ & $\begin{array}{l}\text { Insufficient or not } \\
\text { active position of } \\
\text { participation in the } \\
\text { partnership } \\
\text { relations through } \\
\text { acknowledgement } \\
\text { of the value of } \\
\text { partnership } \\
\text { relations } \\
\text { obtaining for } \\
\text { knowledge and } \\
\text { skills }\end{array}$ & $\begin{array}{l}\text { Week and passive } \\
\text { position of } \\
\text { participation in } \\
\text { the partnership } \\
\text { relations through } \\
\text { acknowledgement } \\
\text { of the value of } \\
\text { partnership } \\
\text { relations for } \\
\text { obtaining } \\
\text { knowledge and } \\
\text { skills }\end{array}$ \\
\hline & $\begin{array}{l}\text { 2.4. Acknowledgement } \\
\text { and awareness of impact } \\
\text { of the partnership } \\
\text { relations on the growth of } \\
\text { attributive components in } \\
\text { learning such as success } \\
\text { and effectiveness }\end{array}$ & High level & Medium level & Low level \\
\hline
\end{tabular}




\begin{tabular}{|c|c|c|c|c|}
\hline Criteria & Indicators & \multicolumn{3}{|c|}{ Forming Levels } \\
\hline $\begin{array}{l}. \\
\text { Behavioral } \\
\text { activity }\end{array}$ & $\begin{array}{lr}\text { 3.1. Focus on } & \text { common } \\
\text { participation } & \text { in } \\
\text { partnership relations } \\
\text { through realizing certain } \\
\text { common partnership } \\
\text { events (actions) }\end{array}$ & $\begin{array}{l}\text { Active position of } \\
\text { common } \\
\text { participation in the } \\
\text { partnership } \\
\text { relations through } \\
\text { the ability to realize } \\
\text { certain common } \\
\text { partnership events } \\
\text { (actions) }\end{array}$ & $\begin{array}{l}\text { Insufficient or not } \\
\text { active, though } \\
\text { existing position of } \\
\text { common } \\
\text { participation in the } \\
\text { partnership } \\
\text { relations through } \\
\text { the ability to realize } \\
\text { certain common } \\
\text { partnership events } \\
\text { (actions) }\end{array}$ & $\begin{array}{l}\text { Weak position of } \\
\text { common } \\
\text { participation in } \\
\text { the partnership } \\
\text { relations through } \\
\text { the ability to } \\
\text { realize certain } \\
\text { common } \\
\text { partnership } \\
\text { events (actions) }\end{array}$ \\
\hline & $\begin{array}{l}\text { 3.2. Focus on the } \\
\text { effectiveness efficiency } \\
\text { and synergy of common } \\
\text { activities }\end{array}$ & $\begin{array}{l}\text { High level of focus } \\
\text { considering the } \\
\text { ability to receive } \\
\text { synergetic effect }\end{array}$ & $\begin{array}{l}\text { Medium level of } \\
\text { focus taking into } \\
\text { account all the } \\
\text { prospectives of } \\
\text { receiving the } \\
\text { efficient result }\end{array}$ & $\begin{array}{l}\text { Minimal or low } \\
\text { level of focus } \\
\text { through the } \\
\text { prospectives of } \\
\text { receiving efficient } \\
\text { result }\end{array}$ \\
\hline
\end{tabular}

Tab. 1. Classification of the criteria indicators and levels of forming partner relations between teenagers. Source: author's proposal.

\section{CONCLUSIONS}

To summarise all the above, it may be concluded that in the research were generalized certain scientific approaches and was presented the classification of components, criteria, indicators and levels of forming the partnership relations between teenagers. The given classification brings to the consideration of three components which are motivational-value, cognitive and activity component, as well as presented criteria, indicators and levels of their manifestation. The structure and the content of this classification considers the main scientific approaches in the given area and tends to universalize modern scientific points of view, as they take into account most of the views and features of the structural components of the partnerships between teenagers. The points of the classification can be used to create methodological support for assessing the mentioned question. Thus, indicators and levels identified in the study may serve as assessments. The defined features of the specified components, criteria, indicators and their levels correspond to those features of the studied age group of teenagers at school educational environment.

\section{REFERENCES}

[1] Burelomova A.S. Socio-psychological characteristics of the values of modern adolescents: candidates thesis. Moscow, 2013. (in Russian)

[2] Ushakov D.V. The structure and dynamics of intellectual abilities: candidates thesis. Moscow, 2004. (in Russian)

[3] Zaitseva M.Yu. Formation of adolescents' ability to cooperate in the conditions of sports and recreation activities. Publishing house "Udmurt University", Izhevsk, 2013. (in Russian) 
[4] Dorontsova O.A. Psychological and pedagogical determinants of the development of adolescent autonomy in the educational process: candidates thesis. Bryansk, 2019. (in Russian)

[5] Crawford A., Saul E.V., Matthews S., Mackinster J. Technologies for developing students' critical thinking. Pleiades, Kyiv, 2006. (in Ukrainian)

[6] Drozdov N.A. Social partnership in education: the essence and content of the concept. Izvestia RGPU im. A.I. Herzen, 180 (2016), 68-72. (in Russian)

[7] Woytkiewich D. Interactions of students and teachers in the school environment. Pedagogical Review, 2 (2011), 88-93. (in Polish)

[8] Gordeeva T.O. Motivation of educational activities of schoolchildren and students: structure, mechanisms, conditions for development: candidates thesis. Moscow, 2013. (in Russian)

[9] Shigabetdinova G.M. Partnership as constructive interaction: theoretical exposition of the problem. Basic research, 3 (1) (2014), 193-196. (in Russian)

[10] Lavrentyeva O.A. Formation of social responsibility of adolescents in the life of the school: candidates thesis. Novosibirsk, 2016. (in Russian)

[11] Kochanova O.P. Partnership as a factor of socialization of the individual. Pedagogical process: theory and practice, 2 (2013), 196-205. (in Ukrainian)

[12] Kapusta Y.S., Onipko V.V. About interaction and partnership relations in pedagogical activity. Methods of teaching natural sciences in secondary and higher school, 1 (2015), 84. (in Ukrainian)

[13] Ivanov S.A. Social partnership as a phenomenon of civilization. Journal of Sociology and Social Anthropology, 3 (2005), 79-99. (in Russian)

[14] Struzynski K. Pedagogical sense of assessment - communicating the results. School director, 4 (2006), 3337. (in Polish)

[15] Moravska I. Assessment at school as interactive communication. Annales N - Educatio Nova, 4 (19) (2019), 196-211. (in Polish)

[16] Shufnarowska M. Formative and summative assessment (attempted comparison). Everything for the School, 4 (2010), 11-12. (in Polish)

[17] Vesolovska E. Assessing students with a decision of a psychological and pedagogical counseling center. Inspirations, 5 (2004), 17, 18. (in Polish)

[18] Zhelanova V.V. Criteria and indexes of formed of refleksiv constructs of a future Teacher of primary classes in the system of context studies in higher educational establishments. Scientific Bulletin of Uzhgorod University: Series: "Pedagogy", 26 (2013), 72-74. (in Ukrainian)

Address: Inna Cimsit, Borys Hrinchenko Kyiv University, 18/2 Bulvarno-Kudriavska St., Kyiv 04053, Ukraine.

E-mail: i.korabelska.asp@kubg.edu.ua.

Received: 13.02.2021; revised: 17.03.2021.

Сімсіт Інна. Критеріальний апарат дослідження стану сформованості партнерських взаємин підлітків в освітньому середовищі закладу середньої освіти. Журнал Прикарпатського університету імені Василя Стефаника, 8 (1) (2021), 193-204.

У статті узагальнено наукові підходи та представлено класифікацію компонентів, критеріїв, показників та рівнів сформованості партнерських взаємин підлітків. У рамках даної класифікації досліджено три компоненти сформованості партнерських взаємин підлітків, а саме, мотиваційноціннісний, якому відповідає аксіодогічний критерій; когнітивний, що визначається операційнокогнітивним критерієм; діяльнісний, який характеризується поведінково-діяльнісним критерієм. Стосовно кожного з критеріїв виокремлено показники й рівні, які їм відповідають. Доведено, що до 
показників аксіологічного критерію за даним напрямом відносяться: показники, що грунтуються на розвитку сформованості партнерських взаємин підлітків через активізацію мотиваційно-ціннісних інтересів і потреб особистості; показники, визначені в контексті орієнтиру на соціальну відповідальність підлітків в умовах партнерських взаємин. Встановдено, що серед показників операційно-когнітивного критерію в цій сфері віднесено: показники, що базуються на виокремденні їх елементів, характерних для вказаної вікової групи (підхід за віковою ознакою); показники, що грунтуються на елементах усвідомлення та сприйняття; показники, визначені в площині орієнтиру на конструктивні результати формування знань та навичок від партнерських взаємин підлітків (конструктивістський підхід) (конструктивістський підхід); показники вказаної категорії, сформовані у рамках акценту на атрибутивному підході до навчальної діяльності. Визначено, що до скдаду показників поведінково-діяльнісного критерію віднесено: орієнтир на спільну участь у партнерських взаєминах через можливість реалізації певних спільних, партнерських заходів (акцій); орієнтир на результативність, ефективність та синергетичність. Структура, зміст зазначеної класифікації враховує основні наукові підходи за вказаним напрямом, передбачає універсалізацію положень сучасної наукової думки, оскільки враховуе більшість поглядів та ознак даних структурних компонентів сформованості партнерських взаємин піддітків. Положення зазначеної кдасифікації можуть бути використані для створення методичного забезпечення оцінки даної проблематики, показники, рівні, наведені в дослідженні можуть виступати у якості оціночних. Встановлено, що окреслені характеристики зазначених компонентів, критеріїв, показників та їх рівнів відповідають характеристикам досліджуваної вікової групи піддітків шкільного освітнього середовища.

Кдючові слова: мотиваційно-ціннісний компонент, когнітивний компонент, діяльнісний компонент, партнерські взаємини підлітків, конструктивістський підхід, соціальна відповідадьність, атрибутивний підхід, результативність. 